\title{
Bérénice Hamidi-Kim
}

\section{Post-Political Theatre versus the Theatre of Political Struggle}

\begin{abstract}
In this article Bérénice Hamidi-Kim tests the hypothesis that two conflicting interpretations of the notion of 'political theatre' exist on the French stage today. She suggests that each is based on a specific ideology stemming from a specific conception of history and policy, which results in a legitimation of the theatre and of artists both in the theatrical field and in society at large. One, which she calls 'post-political theatre', seems to proceed from a radical anthropological and political pessimism, and has deliberately severed all links with all previous forms of political theatre and given up any revolutionary ambitions. The other, which she calls 'political-struggle theatre', proudly embraces the legacy of the earlier forms of revolutionary political theatre - the epic form of documentary theatre in particular and is attempting to revive the political ambition of contributing to a comprehensive, coherent critical project, based on the assumption that theatre is a preparatory school for reality and for political action. Bérénice Hamidi-Kim's doctoral thesis was entitled 'The Cities of Political Theatre in France from 1989 to 2007'. She is also author of 'Quelle place politique et culturelle pour le cadre de l'Etat-Nation dans le théâtre de gauche français?' in the e-review Sens Public (2006), and of 'Théâtre populaire, immigration, intégration, et identité nationale', forthcoming in the February 2008 issue of Etudes Théâtrales.
\end{abstract}

- It's theatre - that's right - for a world in which theatre itself has died. Instead of the outmoded conventions of dialogue and socalled characters lumbering towards the embarrassing dénouements of the theatre, Anne is offering us a pure dialogue of objects ... She's offering us no less than the spectacle of her own existence, the radical pornography if I may use that overused word - of her own broken and abused - almost Christ-like body.

- An object in other words. A religious object.

- An object, yes. But not the object of others, the object of herself. That's the scenario / she offers.

- But surely we've seen all that. Haven't we seen all that in the so-called 'radicalism' of the sixties stroke seventies? ...

- Seen it - perhaps. But not seen it afresh, not seen it now, not seen it in the context of a post-radical, of a post-human world where the gestures of radicalism take on new meaning in a society where the radical gesture is simply one of entertainment i.e. one more product - in this case an artwork - to / be consumed. ${ }^{1}$

IN MY VIEW, this excerpt from Attempts on Her Life by Martin Crimp epitomizes a leading trend on the French stage today, which I will call 'post-political theatre' - 'post' conveying an idea of distance, an estrangement proceeding from a judgement all the more final as it was passed after the event, with the benefit of hindsight; 'post-political' since this new form of theatre was born after the 'official' demise of political theatre and of politics. In order to be fully grasped, both the orientations of this theatre and the success of its figureheads require an interpretation of today's world from a directly political angle. In this respect, what seems to characterize this form of theatre is less the critical stance maintained by dramatists than the fact that it is altogether determined by the context in which it originated.

For all that, the current situation does not necessarily inspire such an interpretation of the world, which is why this post-political theatre must in turn be put in perspective. Indeed, a completely different interpretation of the political situation and of the situation of political theatre is currently offered by other French playwrights, giving rise to a contrasting form of theatre which I will call 'political-struggle theatre', and which seems 
to enjoy renewed favour in the early twentyfirst century. Through an analysis of productions from the 2006-2007 theatrical season, I will attempt to distinguish between these two forms.

\section{Post-Political Theatre}

Post-political theatre is based upon a conception of culture, a conception of theatre, and a conception of policy which are all simply non-starters, since they fall within the axiological framework of a 'post-' world - a post-modern, post-human, and mostly postpolitical and post-radical world. It perfectly fits into the post-modern framework as initially defined by Jean-François Lyotard namely the abandonment of the framework of modernity inherited from the Enlightenment, the closure of all the great founding stories, and the end of a teleogical conception of history based on a belief in Reason that moves towards an end conceived both as a termination point and as an aim to be achieved. $^{2}$

This questioning of the framework of modernity pervades the work of Edward Bond and is the foundation of his postapocalyptic, post-human plays. I am here referring to the important paratext made available during the performances of Naître at the Théâtre de la Colline under the title 'Edward Bond's Drama': ${ }^{3}$

Three hundred years ago was the Age of Enlightenment. At that time, people were told to use their reason, to be accountable for their own actions. . . But we are no longer true to the spirit of the Enlightenment. . . . Instead of reasoning, we are always calculating. The shadow of the Enlightenment, in which we live today, is highly destructive because we are back to the time when God's voice used to dictate to people what they were to think. But today, it is the voice of the devil telling us how to calculate. ${ }^{4}$

More generally, post-political theatrical works are pervaded by this post-human component connected with renewed references, taken out of their historical context, to the Holocaust. Bond thus forcefully asserts (as he has done elsewhere) what lies at the very heart of his being and his work: 'I am a citizen of Auschwitz and of Hiroshima. ${ }^{5}$

It is important to refer to the beautiful, sombre essay by Catherine Naugrette describing these paysages dévastés, aesthetic ruins founded on a darker-than-night anthropological pessimism. ${ }^{6}$ Everywhere Evil reigns supreme. Nobody is innocent, neither individual nor society, and the future holds no promise of change. This theatre is based on the assumption that any political theatre aiming at changing the world in a radical, revolutionary way is utterly impossible. In this respect, even more than the Holocaust, it is the slow disintegration of the Marxist critical project that seems to constitute the foundation stone for post-political theatre.

However, it is possible to detect two coexisting yet contradictory theories underlying it. On the one hand, Francis Fukuyama's already outdated theory of the end of history has left a lingering impression that all major ideological conflicts are now things of the past. $^{7}$ The demise of the Soviet empire has tolled the knell of the revolutionary ideal, now replaced by the unchallenged 'democratic' ideal so that, in Western democracies, the course of history has supposedly come to a final halt.

On the other hand, post-political theatre can be said to be founded on another theory, the 'clash of civilizations', which is a direct contradiction of Fukuyama's. This theory was taken up again by Samuel Huntington in 1993 and became immensely popular in the late $1990{ }^{8}{ }^{8}$ The dramatic changes in the world's geopolitical order since 1989 might have been considered as evidence that political events and indeed political upheavals are continuing to take place, contributing new chapters to a history still in the making. However, history is not central to the theory of the 'clash of civilizations', which focuses rather on the insurmountable nature of conflicts.

This interpretation gained new momentum after 2001, feeding on the fear of terrorist attacks hatched in the shadows by an enemy both faceless and many-faced, omnipresent and elusive, as befits a chaotic world where violence reigns supreme and whose only 
coherence lies in the inability of human beings to live together for want of universal values and ideals.

\section{Aesthetic Consequences}

These representations of the world seem to have become part and parcel of post-political theatre, infusing an aesthetics based on the disruption and disintegration of the character, of any coherent vision of the world, of the dramatic fable, and of the history of the theatre. To begin with, character has disintegrated, giving way to a multifaceted figure in keeping with a certain vision of humanity and the world. The title of Martin Crimp's play makes it quite clear that attempts are being made on the heroine's life while attempts are simultaneously being made to work her out. Even her name keeps changing, since she is referred to both as Anny and Anne, which signals the elusiveness of the sign and, in particular, of its actual referent.

This unravelling of dramatic art results in a display of extreme violence on stage, the characters being literally broken down into body parts before our eyes. Here I am referring to the final sequence, 'Pornó', of the play as directed by Joel Jouanneau. Using a webcam, one of the male actors firmly holds in position the actress in the role of Anne, while filming fragments of her body in closeup: her crotch, her cleavage, her pink wig. Her body is broken into bits and pieces. He then moves to her face, the mouth of this woman being so heavily made up that the face all but disappears beneath a death mask; and lastly to her eyes (formerly thought of as the windows of the soul), which are dissected by a scalpel-like camera that seems to violate not just the body but also the innermost recesses of the mind and indeed the very soul of the young woman, whom the director conceives as embodying a prostitute from Eastern Europe as much as a blue movie actress. ${ }^{9}$

Not only has the character disintegrated in post-political theatre, but the very existence of the Aristotelian fable is being challenged, as is the teleological conception of history. And so also has the Brechtian epic fable, the foundation of what Bernard Dort called 'theatre as a prep school for real life' (one might add, a prep school for political action), come under attack. ${ }^{10}$

Post-political theatre is, first and foremost, a metadiscursive theatre, which feeds upon its own untenability and keeps recycling material so as to supersede all the previous forms of the theatre; it quotes and recycles these two major models, playing one against the other so as to discredit them both. Ideology and aesthetics intermingle inextricably in this metatheatre which has done away with dramatic and political action and, instead, harps on its own untenability. Defining itself through a rejection of all critical representation - that is, of all global attempts at assessment - it focuses strictly on the inner world which it portrays in an unprocessed, rough and ready way rather than through representation.

As a result, this type of theatre wavers between three options. First, it may be reduced to an avowed inability to speak about the world in a coherent, distanced way. This is what seems to be suggested by the stage design and the dramatic construction of the show Les Marchands by Joël Pommerat. ${ }^{11}$ Then, some of the post-political dramatists still set great store by 'real life' and continue to draw their inspiration from epic dramas, which, according to Bernard Dort, fall into the category of 'real-life theatre', but with the major difference that they no longer purport to represent a divided world as a preparation for political action. They are content with portraying a fragmented world riven with contradictions and violence. The point is no longer to try to make more sense of the world by showing the connections between the footnotes of history and individual destinies; it is merely to depict a chaotic, violent world.

Oxygène by Ivan Viripaïev, as directed by Galin Stoev, seems to epitomize this intention to express but not to represent a world conceived as an incoherent, contradictory place. ${ }^{12}$ Indeed, the author seems to adhere to the theory of the clash of civilizations:

In the same way as the sight of a fat, trousered woman gorging herself on pork-filled hamburgers 
may be offensive to a Muslim, it was equally disagreeable for David Hoferman from New York to discover a woman's scalp on his window sill following the Twin Towers blast, after the owner of this scalp, a fat trousered woman, was sent on her way to the Muslim Hell on the grounds that her stomach still contained ill-digested pork. ${ }^{13}$

\section{'Irreconcilable Differences'}

The fat trousered lady, the Jewish New Yorker, and the Muslim terrorist are so many emblematic figures of the clash of civilizations. And the idea that it is utterly impossible for human beings to live together is echoed in the private sphere by the impossible love between the two Sashas, who are driven apart not just by their cultural differences, but by a more fundamental impossibility, of human beings striking up and maintaining relationships.

'Irreconcilable differences' and disputes seal the divorce between individuals and cultures, thus tolling the knell of social harmony, which is the very foundation of political communities. They also toll the knell of the intrinsically political role of the theatre this legacy of antiquity operating as the mental base of policy', as Christian Meïer puts it. ${ }^{14}$

It is highly significant that the director should reject the very principle of a pièce $\grave{a}$ thèse, accusing it of being necessarily oversimplistic, of portraying things in black and white. ${ }^{15}$ On the contrary, any coherent, literal meaning is deliberately obfuscated by means of two main techniques. Irony, first (which of course raises the problem of misunderstandings on the audience's part), and, then, the fact that this is both a concert and a play [théâtre-concert], incurring the risk that spectators carried away by their senses and by the rhythm of the music will forget all about meaning and will unwittingly assent to anything, since according to the director the author

piles on, at a furious pace, a spate of words, a flood of convoluted, paradox-ridden arguments. What we have here is not so much a text to be made intelligible to the audience as a music score, a rhythmic, energetic framework, which argues its points by means of a frantically paced concert. ${ }^{16}$
Emphasis on sensory reception also characterizes post-political theatre, which confirms its rejection of consistency and of any wellargued discourse about the state of the world. In this way, this form of theatre is a reversion to a 'happening', often synonymous with unprocessed, Christ-like suffering, truly experienced by the actors on stage as well as vicariously by the audience. The artist suffers on behalf of the world; possibly (s)he also suffers because (s)he is incapable of changing the world.

Fées by Ronan Chéneau was written, directed (by David Bobée), and interpreted by artists who define themselves as 'those thirtysomethings who are proving unable to rebuild the world they inherited from their parents, and are feeling terribly guilty as a result ${ }^{\prime}{ }^{17}$ This team can be said to draw inspiration from the revisited work of Rodrigo Garcia, with added rigour and maturity. This goes for the writing as well as for the stage direction, or the borrowings from the art of 'happenings'.

The stage is occupied by a bathroom flanked by two walls. Tiers on either side of the stage accommodate the audience so that its members are facing each other. Thus, each spectator is literally facing himself while his attention is irresistibly drawn to the stage, which symbolizes both a withdrawal to the intimacy of a private place and the loneliness of the only character with a real-life equivalent: 'a Caucasian, free individual in his late twenties' - the two female characters being fairies. ${ }^{18}$ Both the stage design and the lighting are clearly influenced by the visual arts, in particular installations and 'happenings'. The fact that there are seats on both sides of the stage turns the latter into an arena and conveys the impression that the male actor is a fighter for (not to say a martyr to) meaninglessness. Relentlessly, the fairies keep questioning him about the emptiness of his life:

You wanted to know ...

Whatever for? You rose

one day ...

you rose and stood on your own two feet

but whatever for?

Whatever for? ${ }^{19}$ 
'Obviously, we'll never become heroes,' the male character keeps repeating. ${ }^{20}$ And it seems that he is trying to atone for this crime, to redeem his guilt, whenever he springs out of his womb-like bath only to flop heavily on the floor and flounder there like a fish out of water, fighting for breath. After lying dying with his legs curled up in a foetal position, he retreats into the bath, then starts all over again, never managing to deliver himself from the womb. Each and every time, he thuds heavily on the floor.

At some other point, out of childlike playfulness or childlike cruelty, the actor hurls balls at one of the fairies, aiming at her head, her leg or her breasts. He never fails to hit the mark, as the purple bruises on the actress's body clearly show. In this play, however, violence is not merely expiatory, nor is it wholly gratuitous, as evidenced by the last scene, when one of the fairies puts on a mask representing the Statue of Liberty and then picks up one of the hundred green bottles of shampoo - all of different shapes and brands - strewn over the floor. To the accompaniment of syrupy rock music, she starts pouring shampoo on her eyes and into her mouth, trying to maintain her balance as the white, gooey liquid which is dripping onto the floor threatens to make her lose her balance. This jerky dance forcefully symbolizes the genuine blindness and collapse of the ideal embodied by the American empire.

At the heart of this show lies what, in my view, constitutes the third option for this post-political theatre, which consists in simultaneously exposing and reasserting the utter impossibility of making political commitments in today's world. The scene takes place in a bathroom, and water - a highly significant element in psychoanalysis - plays a large part in the show. Water is closely associated with regression, but it can also suggest decomposing flesh, especially as a bleak atmosphere is created by the white tiled floor and the eerie, green lighting that makes the two fairies look as wan as ghosts.

The cold, artificial lighting, the omnipresence of water, the symbolic correspondences - all tell about a symbolic universe haunted by death and decay, lulled into a deadly sleep by the caressing whispers of the actresses. The sudden switch to a harsh, red lighting just when one of the fairies embarks on an angry speech is itself a revolution. Which is precisely what she is calling for: 'What we need is a revolution.' ${ }^{21}$ But it is a right-wing revolution, since the speech she delivers with raised fist is a reactionary one, reviling not only civil servants and immigrants but also (indeed mostly) the left-wing parties 'that want purging from their old mouldy, Marxist demons, which smell as bad as rotten fish. ${ }^{22}$

Is this antiphrasis, as the actress's hysterical, tongue-in-cheek acting tends to suggest? Of course, none of the actors, any more than the director or author, adheres to the views expressed at this point, as they make quite clear when they meet with the audience after the performance. Nevertheless, what the show does suggest is that, to a certain extent, the political parties currently putting forward revolutionary ideas are right-wing parties, and not just of the extreme right. The point is that no revolution can be expected from the younger generation, although it is depicted as potentially attracted by left-wing values. Because, as the male character keeps repeating, "There is no beach these days under the pavement' or 'I am a man of my time, I am an individualist, I just can't help it. ${ }^{23}$

\section{The Revival of Political-Struggle Theatre}

However, this post-political trend is currently offset by a completely different one, disproving the theory that post-political theatre would offer an unbiased, incontrovertible portrayal of the state of the world, of society, of politics, and of political theatre. Indeed, from the 2006-2007 theatrical season one could also draw the impression that we are witnessing a revival of political-struggle theatre.

Equally dissatisfied with the present state of the world, this theatre does not lay the blame on the ontological, unredeemable guilt of human beings in general, but on particular people and particular political systems. The present political and economic circumstances, which are especially difficult in 
France and, indeed, in the whole of Europe, are revitalizing the conception of a divided world and the idea that dramatists should play the role of critics on behalf of one of the two political camps - namely, that of the weak, considered not as ontological victims, but as the downtrodden, oppressed by a system whose machinery must be brought to light and exposed. These playwrights take account of the two major watersheds, the Holocaust and the collapse of the communist ideal, but they consider them precisely as incentives to arouse new hopes of struggle for a better world.

This political-struggle theatre offers a fresh combination of the two features which, according to political scientists, characterize politicization. The first is called a 'rise in generality' (montée en généralité). What this means is that one starts from a particular, anecdotal case and infers from it a more general perspective, which is then used to throw light on the case in question, to put it at a distance, and eventually to modify it.

The second feature, called 'conflictualization', may today be clad either with the ancient but by no means outmoded clothes of agon, or with those of philosophical dispute. Or it may adopt brand new clothing, the objective of the playwright being invariably to throw light on today's political order. What also characterizes this theatre is that, far from making a clean sweep of political history or of its own history, it embraces anew the question of political commitment and its theatrical forms.

\section{The Revival of Documentary Theatre}

Among the most highly thought of legacies of the theatre of conflict is documentary theatre. It appears quite as topical in this day and age (if not more so) as at the time when Peter Weiss published his 'Fourteen Theses on Behalf of Documentary Theatre', insofar as the object of documentary theatre is not so much real events as the way they are covered by the mainstream media. The revival of Peter Weiss's The Investigation: Oratorio with Eleven Cantos, directed at the Bouffes du Nord theatre by Isabelle Gyselinx and Dorcy
Rugamba (a Rwandan actor-director-author who was in the cast of Rwanda 94 along with other Rwandan actors), clearly demonstrates how the Holocaust can be put in a historical perspective and offer fresh insights into contemporary events. ${ }^{24}$

The ending of the play is an indisputable legacy of dialectical theatre. In a final sequence added to the original play, two conflicting interpretations of the Auschwitz trial are proposed. One of the actors draws a parallel between this historical event and the still topical struggle between exploiters and exploited people (as in Third World countries: France against Rwanda, for instance), whereas another sweeps this interpretation aside with what has now often become an insult: 'This is sheer ideology.'

The strongest suit of documentary theatre lies not only in political insight and acumen, but also in the variety of aesthetic approaches it makes possible. Thus, in Fausto Paravidino's Gênes, 2001, as directed by Stanislas Nordey, the formalism of tragedy beautifully furthers the mission of counter-information which has become indispensable at a time when political and media power is becoming increasingly concentrated in a few hands. ${ }^{25}$

The play is an interrogation concerning freedom of speech and the drift towards fascism observed in Italy under the rule of Silvio Berlusconi. If one considers the bare facts, the threat appears all too real. Apart from Carlo Giuliani's death, what we have here is a catalogue of racist, sexist insults, sexual assaults, various acts of violence, identity papers being confiscated, evidence being manufactured, and identities being usurped. But to a French audience, these revelations are accompanied by the equally disturbing fact that, at the time, they were not properly covered by the French media. Almost everything brought to light by Fausto Paravidino (who regretted being unable to supply hard evidence to substantiate it) has since been established beyond dispute - which is all the more unfortunate as such facts are liable to terrify not just the advocates of political revolution but even the mildest supporters of democracy. This is made clear by Donnatella Della Porta and Herbert Reiter's article, 
'Antiglobalization and Law and Order: the G8 Summit in Genoa'.26

The play and the production are much more than a simple testimony showing antiglobal demonstrators in a favourable light. They somehow justify their struggle by describing the serious lapses of a democracy that allows repression and disinformation along with the appropriation of the public arena and of public goods by private interests. As to the political commitment of the younger generation, the young student-actors of the Théâtre National de Bretagne certainly do not show the disaffection with politics proclaimed in Oxygène or Fées.

\section{The Fight for 'Liberty, Equality, Fraternity'}

France's breaches of its own democratic and even republican ideals are yet more directly questioned in a number of productions, which contrast her noble motto, 'Liberty, Equality, Fraternity', with current events those concerning immigration, in particular. In his largely autobiographical work Une Étoile pour Noël, ou l'ignominie de la bonté, Nasser Djemaï reinvents the one-man comic show, a popular entertainment through which French second-generation immigrants such as Jamel Debbouze, Smaïn or Fellag, have become famous. He also reinvents the hybrid character Mohamed, first created by Kateb Yacine, a son of Scapin and of the former French colonies. $^{27}$

The choice of comedy enables Nasser Djemaï to unite and divide his audience simultaneously, better to question the French way of integrating immigrants. One of the key characters is a grandmother who starts to take a liking to her grandson's immigrant friend when, to her surprise, she finds out that 'little Nabil' is brighter and keener to learn than her own grandchild. It is therefore with the best of intentions that she urges him to dye his hair, get rid of his accent, and eventually change his first name to 'Noël'. And it is by complying with his father's demands that Nabil comes to despise and even, in some ways, to disown him.

For his part, Mohammed Rouahbi in Vive la France! demolishes some of the rampant clichés and misconceptions about immigrants, in particular about the young residents of les banlieues (the French equivalent of British or American inner cities) and about the urban riots that took place in $2005 .{ }^{28}$ Contrary to what the title of the production or the programme distributed to the audience might lead one to expect, the performance opens with a ten-minute sequence of recorded voices heard in semi-darkness. First is the voice of M. Rouahbi, whose face is barely visible on a backcloth lit in chiaroscuro - a subtle hint that the faces of old immigrant workers are now fading from our memories. From the outset, his words are in stark contrast with the Republic's motto, describing 'a world where it is no longer enough to belong to the human race to see one's dignity acknowledged and respected' and putting forward the brutal truth that 'a class-ridden society cannot be anything but a violent society'.

Then, it is the turn of the residents to speak - the teenagers and young adults, of course, but also their mothers, who in November 2005 were often accused of failing to assume their parental duties. This is followed by a flood of idealized images of immigrants which defuse and explode the usual stereotypes through their very accumulation. Footage of recent events is shown during the performance, along with contradictory library pictures, and these correct one another in a tireless sequence whose aim is to put immigration in a historical perspective and to retrace its history.

The point is not to excuse the rioters' violence, but to show that it may have been a reaction to police brutality - a number of press articles about police blunders being shown on screen. In addition, the violence is not meant to obscure the feeling of injustice that prevails in these suburbs due, among other things, to the impression that the background to immigration is not widely recognized. 'The contempt in which this history of immigrants is held will always be interpreted as a contempt for the immigrants themselves,' one of the young actors exclaims. Mention is also made of the bill exhorting French history teachers to under- 
line the benefits of colonization in the classroom. ${ }^{29}$

As an artist, a citizen, and a left-wing militant, M. Rouahbi ceaselessly replies to the arguments put forward by the right, in particular those of the leader of the UMP party (Nicolas Sarkozy), whose statements can almost be considered the main thread of the show. But it is also a warning against the cleverness of the National Front, especially when one of the young amateur actresses, who wears an eyepatch, repeats part of a speech delivered by Marine Le Pen, the latter's recorded voice being superimposed on the actress's voice. This is a way to remind the audience of the growing influence of the National Front over young people and to remind them that, even more than her father, Marine Le Pen scores a point when she asks:

Who are the true racists? Us, or rather those who want to let in unlimited numbers of foreigners without guaranteeing them means of livelihood? Us, or rather those members of the Socialist Party who send their kids to private schools and have their fair-haired little ones looked after by black nannies? ${ }^{30}$

\section{Theatre as a Mouthpiece of Suffering}

Political-struggle theatre is currently being given renewed life not just by the children of first-generation immigrants or by the issues which concern them. Judging by the programme of the 2006-2007 theatre season, (and of the previous year's, for that matter), the most frequently debated issue seems to be that of changes in the workplace. The conditions of working-class life are at the heart of L'Usine, a play by Magnus Dahlström, first performed in France under the direction of Jacques Osinski at the Théâtre du Rond Point in Paris during January and February 2007.

Its description of how deteriorating working conditions are dehumanizing personal relations, driving some workers to despair and even suicide, painfully brought to mind recent tragedies in the workplace. On 22 January 2007 yet another employee of the Renault Technocentre in Guyancourt took his own life, bringing to five the total number of workers - engineers as well as people on the shop floor - who attempted or managed to commit suicide in that particular workplace over the past two years.

Executives are nowadays as hard hit by the deterioration of working conditions as workers on the shop floor, a novel situation brought about by economic liberalism, which is currently subjected to meticulous analysis by a great many playwrights, from Emmanuel Darley, whose most recent work Flexible, hop, hop! was performed at the Théâtre Ouvert, to Roland Schimmelpfennig, whose work Push-Up was directed by the DRAO collective company (Derniers Remords Avant l'Oubli, from the title of a play by JeanLuc Lagarce). ${ }^{31}$

The second of these plays has similarities with Top Dogs, seen in the previous year, and was explicitly inspired by two major sociological essays, Souffrance en France, by Christophe Dejours, and Le Nouvel Esprit du Capitalisme by Luc Boltanski and Eve Chiapello. ${ }^{32} \mathrm{Push}-\mathrm{Up}$ is a succession of dialogues, in which executives subjected to cut-throat competition confront each other, and of monologues which, in their similarities, make it abundantly clear that all are in the same boat and would be well advised to join forces instead of being at each other's throats.

The play highlights both the dire consequences of a lack of collective consciousness and the way the changes in management techniques have caused the world of work to disintegrate. Guy Alloucherie, in Base 11/19, also lays the blame equally on the advocates of neoliberalism and on workers who are reluctant to join forces. ${ }^{33}$ This work is partly a collage of quotations from the works of sociologists, philosophers, and experts on the world of work as well as on the political and economic changes in contemporary society. ${ }^{34}$ The urgent need for a well-argued critical discourse on today's world and the values it promotes is made plain on stage by the display of the suffering bodies of working people, the director using circus artists and dancers to express this suffering and to show how difficult it is to live and work in a world which considers competition and profit as the supreme values. 
The political role that should be played by culture is at the heart both of Jean-Claude Wallach's essay on the democratization of culture and of Guy Alloucherie's stocktaking of the work undertaken by himself and the team of 'Culture Commune', a state-funded theatre in the Pas-de-Calais coal basin. ${ }^{35}$ The director Chantal Lamarre is doing what can be considered pioneering work in such a place, trying as she does to combine artistic and political action and to bridge the gap between theatres, artists, and local residents. Her genuine commitment and her strong determination to less talk and more action are evidenced by the fact that she literally broke her wrist when banging on the table to obtain more subsidies from the public bodies who had some misgivings about the artistic merit of such a militant undertaking - an ironic demonstration that political-struggle theatre still does not enjoy the same official recognition as post-political theatre.

\section{Notes and References}

With the author's agreement, the English of this text was modified and improved by Maria Shevtsova.

1. Martin Crimp, Attempts on Her Life (London: Faber and Faber, 1997), p. 50-2.

2. Jean-François Lyotard, La Condition Post-moderne (Paris: Minuit, 1979).

3. Edward Bond, Naître, trans. Michel Vittos (Paris: L'Arche, 2006). Directed by Alain Françon, the play was first performed at the Avignon Festival in July 2006 and then from 24 November to 20 December 2006 at the Théâtre de la Colline in Paris.

4. Edward Bond, Avignon interview, Summer 2006 reprinted in the special issue of the journal of the Théâtre de la Colline, Le Théâtre d'Edward Bond (Paris, Publications of the Théâtre de la Colline, 2006), p. 5.

5. Edward Bond, quoted by Catherine Naugrette in Paysages dévastés: le théâtre et le sens de l'humain (Belfort: Circé, 2004)

6. Ibid.

7. Francis Fukuyama, 'The End of History', National Interest, New York, National Affairs, No. 16 (Summer 1989), p. 3-18.

8. This theory was first set out by Bernard Lewis in The Middle East and the West (London: Weidenfeld and Nicolson, 1964), p. 135. It was subsequently updated by Samuel Huntington in the early 1990s in an article,'The Clash of Civilizations', Foreign Affairs, New York, Council of Foreign Relations, LXXII, No. 3 (Summer 1993), p. 22-49. The theory began to reach a wide audience after the publication of Huntington's book, The Clash of Civilizations and the Remaking of World Order (New York: Simon and Schuster, 1998).
9. Directed by Joël Jouanneau, the play was first performed at the Théâtre de la Cité Internationale, Paris, from 13 November to 6 December 2006.

10. Bernard Dort, 'Une Propédeutique de la réalité', in Théâtres (Paris: Point, 1986).

11. Joël Pommerat, Les Marchands (Paris: Actes Sud Papiers, 2006). The play, directed by Joël Pommerat himself, was first performed at the Strasburg National Theatre in January 2006, then on tour at the Paris-Villette Theatre in December 2006.

12. Ivan Viripaïev, Oxygène, in Les Rêves, Oxygène (Besançon: Les Solitaires Intempestifs, 2005). The play, directed by Galin Stoev, was first performed at the Marni Theatre in Brussels, then on tour at the Théâtre de la Cité Internationale in Paris, from 20 November to 19 December 2006.

13. Ibid., p. 62.

14. Christian Meïer, De la tragédie grecque comme art politique, trans. Marielle Carlier, Les Belles Lettres, 1999, p. 47 .

15. Galin Stoev, interview with Sabrina Weldman 'Etranglement du sens', Mouvement.net, 16.11.2006.

16. Ibid.

17. Ronan Chéneau, Fées (Fairies), Besançon, Les Solitaires Intempestifs, 2005. Directed by David Bobée, the play was first performed at the National Dramatic Centre in Caen in 2004, then on tour at the Théâtre de la Cité Internationale in Paris, from 15 March to 6 April 2007. The quotation is an abstract of the press kit.

18. These words are not to be found in the published version of the text but only in the performed version, as well as in the programmes handed out to the audience at the Théâtre de la Cité. To a large extent, the text heard during the performance differs from the published version, which testifies to the close collaboration between author and director, and to the way David Bobée's team has appropriated Ronan Chéneau's text.

19. Ibid., p. 45-6.

20. Ibid., p. 41 .

21. Once again, this line is absent from the written version.

22. Ibid., p. 63

23. First quotation, ibid., p. 41. The second quotation is absent from the written version.

24. Peter Weiss, The Investigation: Oratorio with Eleven Cantos, trans. J. Baudrillard (Paris: L'Arche, 2000). Directors: Dorcy Rugamba and Isabelle Gyselinx (of the Paf le Chien Company) with the Urwintore workshop in Kigali. The play was first performed at the Théatre de la Place in Liège, Belgium, in November 2005, then on tour at the Bouffes du Nord in Paris from 17 to 21 January 2007. Rwanda 94 was created by The Groupov in 1999, following five years of research into the genocide with Rwandan people. The production was a huge success in Belgium, France, and Rwanda.

25. Fausto Paravidino, Gênes 2001, in Peanuts, Gênes 2001 (Paris: L'Arche, 2004). The play was first performed at the Brittany National Theatre in Rennes in November 2006 and then on tour at the Open Theatre in Paris in December 2006. It is one half of a work in two parts, the other, complementary half being Peanuts, by the same author, which ponders both the link between neoliberal democracy and a police repression that seems to signal a drift towards fascism, and the place and political responsibilities of youth in society.

26. Donnatella Della Porta and Herbert Reiter, 'Antimondialisation et ordre public: le sommet du G8 à Gènes', in Police et manifestants, maintien de l'ordre et 
gestion des conflits (Police and demonstrators, law and order maintenance and dispute management), under Olivier Filleule and Donnatella Della Porta (Presses de Sciences Po, 2006), p. 281-304.

27. Nasser Djemaï, Une Étoile pour Noël, ou l'ignominie de la bonté (Paris: Actes Sud Papiers, 2006). The play, directed by Natacha Diet, was first performed at the Maison des Métallos, Paris, in January 2005.

28. Vive la France!, written and directed by Mohammed Rouahbi. The show, co-produced by La Cité Nationale de l'Histoire de l'Immigration (a museum retracing the history of immigration and colonization), is a work in progress which was launched in 2006. It is supposed to be enriched as time goes by with curren events, and eventually to be completed as a trilogy during the 2008-2009 season. The first version of the show was performed at Canal 93 in Bobigny from 1 to 3 December 2006 and the second at La Ferme du Buisson, during the Labomatic Festival 30-31 March 2007.

29. On 23 February 2005, a law (Act 2005-158) was passed which aimed at 'expressing the Nation's gratitude and acknowledging the national contribution of the French settlers and Algerian soldiers repatriated after Algerian independence'. Article 4, paragraph 2, of this Act stipulated that 'school curricula should make sure to enhance the positive after-effects of the French presence overseas, notably in North Africa, and, by relating their history and their sacrifice, should give those who fought in the ranks of the French army all the credit that is theirs by right'. This paragraph gave rise to a heated debate both in France and overseas. On the one hand, many people regarded it as a paean to colonization and, on the other, a large number of prominen French historians questioned the right of the State to meddle in the way history should be taught in French schools. At President Jacques Chirac's request, Prime Minister Dominique de Villepin eventually submitted the case to the Constitutional Council, asking it to rule on the nature of paragraph 2. The Council ruled that it was of a regulatory (as opposed to legal) nature. This meant that it could be repealed without the Parliament having to discuss it. Paragraph 2 of article 4 of the Act was abrogated by decree on 16 February 2006.

30. Marine Le Pen, quotation from a speech to the Front National in Toulon, June 2006

31. Emmanuel Darley, Flexible, hop, hop!, in Flexible, hop, hop! suivi de Etre humain (Paris: Actes Sud Papiers, 2005). The play was directed by Patrick Sueur and Paule Groleau, and was first performed at the Théatre Ouvert from 12 to 24 March 2007 as part of the 'Carte Blanche' given to Emmanuel Darley. Roland Schimmelpfennig, Push-Up, translation by Henri-Alexis Baatsch, in Une Nuit Arabe et Push-Up (Paris: L'Arche, 2002). The play was first performed at the Théatre de la Tempête in May 2006 and then on tour, notably at the Théâtre 95 in Cergy in December 2006.

32. Urs Widmer, Top Dogs (Paris: L'Arche, 1999). The show, directed by Mathieu Bauer who transformed the play with the Sentimental Bourreau company, was first performed at the National Dramatic Centre in Montreuil from 6 to 28 March 2006. Christophe Dejours, Souffrance en France: la banalisation de l'injustice sociale (Paris: Seuil, 200o), Luc Boltanski and Eve Chiapello, Le Nouvel Esprit $d u$ Capitalisme (Paris; Gallimard, 1999).

33. Base 11/19 was first performed at Culture Commune in Loos-en-Gohelle in January 2007, and then on tour at the Théâtre de l'Odéon-Ateliers Berthier from 8 to 31 March 2007.

34. Danièle Linhart, Perte d'emploi, perte de soi (Paris: Erès, 2000). Stéphane Beaud, Michel Pialoux, Retour sur la condition ouvrière (Paris: Fayard, 2000).

35. Jean-Claude Wallach, La Culture, pour qui? Essai sur les limites de la démocratisation culturelle (L'Attribut, 2006). 